\title{
ASO Visual Abstract: Clear Cell Borderline Ovarian Tumor: Clinical Characteristics, Prognosis, and Management
}

\section{Giulio Ricotta, $\mathrm{MD}^{1}$, Amandine Maulard, $\mathrm{MD}^{1}$, Massimo Candiani, $\mathrm{MD}, \mathrm{PhD}^{2}$, Catherine Genestie, $\mathrm{MD}^{3}$,} Patricia Pautier, $\mathrm{MD}^{4}$, Alexandra Leary, $\mathrm{MD}^{1} \mathrm{PhD}^{4}$, Cyrus Chargari, $\mathrm{MD}^{5}$, Giorgia Mangili, $\mathrm{MD}, \mathrm{PhD}^{2}$, Philippe Morice, MD, $\mathbf{P h D}^{1,6}$, and Sébastien Gouy, $\mathbf{M D}, \mathbf{P h D}^{1}$

${ }^{1}$ Department of Gynaecologic Surgery, Gustave-Roussy, Villejuif, France; ${ }^{2}$ IRCCS San Raffaele Hospital, Vita-Salute University, Milan, Italy; ${ }^{3}$ Department of Pathology, Gustave-Roussy, Villejuif, France; ${ }^{4}$ Medical Oncology, GustaveRoussy, Villejuif, France; ${ }^{5}$ Radiation Oncology, Gustave-Roussy, Villejuif, France; ${ }^{6}$ Paris Sud University Kremlin-Bicêtr, Paris, France

As discussed in our article (https://doi.org/10.1245/s10434021-10776-7), a clear cell borderline ovarian tumor is a rare entity, mainly unilateral and diagnosed at stage I disease. Peritoneal restaging surgery is not required for this stage of malignancy. Synchronous endometrial disorders with atypia are infrequent, suggesting that systematic hysterectomy is not necessary.

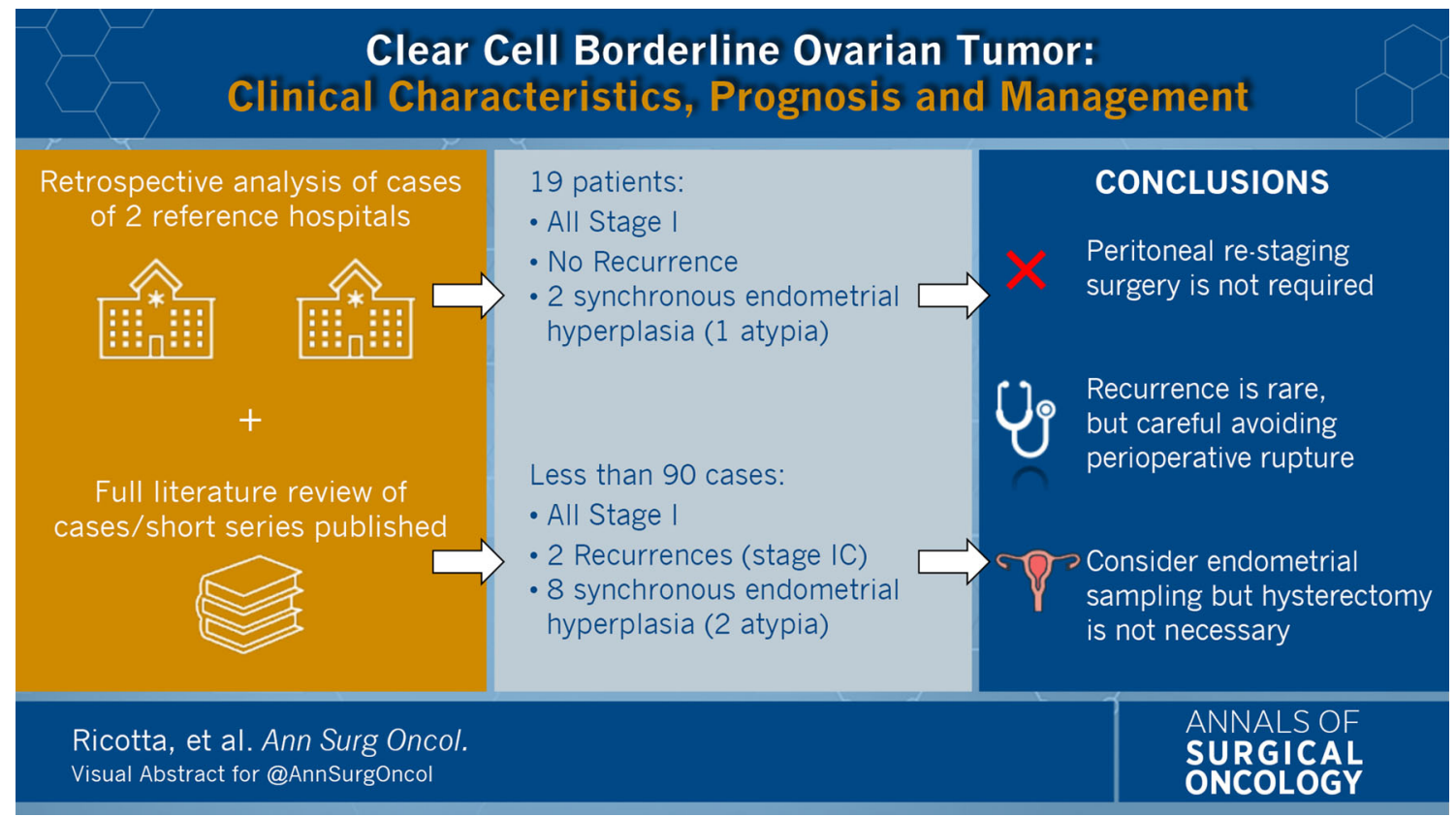

(C) Society of Surgical Oncology 2021

Published Online: 2 December 2021

P. Morice, $\mathrm{MD}, \mathrm{PhD}$

e-mail: Philippe.MORICE@gustaveroussy.fr
Publisher's Note Springer Nature remains neutral with regard to jurisdictional claims in published maps and institutional affiliations. 